\title{
PROBLEMATIKA PENGUJIAN PENYALAHGUNAAN WEWENANG MENURUT UNDANG-UNDANG REPUBLIK INDONESIA NOMOR 30 TAHUN 2014 TENTANG ADMINISTRASI PEMERINTAHAN DALAM PEMBERANTASAN TINDAK PIDANA KORUPSI
}

\begin{abstract}
ABSTRAK
Oleh : Citranu*

Undang-Undang Nomor 30 Tahun 2014 tentang Administrasi Pemerintahan dianggap memunculkan masalah baru dikarenakan pada ketentuan Pasal 21 UUAP membuka ruang untuk melakukan pengujian terhadap tindakan pejabat yang dianggap melakukan penyalahgunaan wewenang, sedangkan berdasarkan UU Korupsi, penyalahgunaan kewenangan termasuk ke dalam tindak pidana korupsi. Sehingga pengujian penyalahgunaan wewenang dianggap menghambat penegakan dan pemberantasan korupsi. Pengujian penyalahgunaan wewenang dalam UUAP tidak akan berdampak negatif terhadap pemberantasan korupsi, karena UUAP bertujuan untuk memberikan jaminan dan kepastian hukum dalam penyelenggaraan pemerintahan di Indonesia, UUAP memberikan ruang kepada Badan dan/atau Pejabat Pemerintahan atau penyelenggara negara lainnya untuk memberikan pelayanan yang berkualitas kepada masyarakat dalam penyelenggaraan pemerintahan, selain itu juga UUAP memberikan perlindungan hukum terhadap Pejabat Pemerintah dalam melaksanakan fungsi pemerintahan, dan tidak ada konsekuensi hukum dari perbedaan hasil penegakan hukum penyalahgunaan kewenangan menurut hukum administrasi dengan penegakan hukum dalam tindak pidana korupsi, karena antara ranah administrasi dan pidana jelas berbeda, walaupun pada ranah hukum administrasi menyatakan bahwa tidak ada penyalahgunaan kewenangan, akan tetapi dalam ranah pidana ditemukan niat jahat dari pada perbuatan menyalahgunakan kewenangan tersebut maka proses pidananya tetap berjalan sehingga proses penegakan hukum administrasi tidak menghalangi proses penegakan hukum pidana. Begitu juga sebaliknya proses penegakan hukum pidana tidak melarang dan membatasi adanya penegakan hukum administrasi baik dalam hal pengujian perbuatan penyalahgunaan kewenangan dikarenakan hukum pidana merupakan Ultimum Remedium. KataKunci: Pengujian Penyalahgunaan Wewenang, Administrasi Pemerintahan, dan Korupsi.
\end{abstract}

\section{PENDAHULUAN}

Ada yang beranggapan lahirnya UU No 30 Tahun 2014 tentang Administrasi Pemerintahan sebagai pelemahan terhadap pemberantasan tindak pidana korupsi di Indonesia, dikarenakan pada Undang-Undang Administarasi Pemerintahan (UUAP) mengatur terkait dengan pengujian 
tindakan penyalahgunaan wewenang oleh Badan dan/atau Pejabat Pemerintahan atau penyelenggara negara lainnya di Pengadilan Tata Usaha Negara yang secara langsung masuk ke dalam ranah hukum administrasi. Sebagaimana diketahui penyalahgunaan kewenangan merupakan salah satu bentuk tindak pidana korupsi yang termasuk dalam ranah hukum pidana.

Pada Pasal 21 UUAP secara tegas mengatur "(1) Pengadilan berwenang menerima, memeriksa, dan memutuskan ada atau tidak ada unsur penyalahgunaan Wewenang yang dilakukan oleh Pejabat Pemerintahan." Pengadilan disini adalah pengadilan tata usaha negara.

UUAP dianggap menghalangi proses penegakan hukum terkait tindak pidana korupsi, akan tetapi disatu sisi dengan adanya ketentuan yang mengatur terkait pengujian penyalahgunaan wewenang dalam UUAP menjamin kepastian hukum bagi pejabat yang menjalankan wewenang pemerintahan, dikarenakan selama ini dengan adanya kesalahan administrasi sedikit saja langsung dikenakan tindak pidana korupsi padahal belum tentu ada niat jahat untuk melakukan korupsi. Berdasarkan hal tersebut diatas penulis tertarik melakukan penelitian hukum dengan judul : Problematika Pengujian Penyalahgunaan Wewenang Menurut UU No 30 Tahun 2014 Tentang Administrasi Pemerintahan Dalam Pemberantasan Tindak Pidana Korupsi.

II. ketentuan pengujian penyalahgunaan wewenang dalam UUAP akan berdampak positif atau justru negatif terhadap pemberantasan tindak pidana korupsi?

Sebelum lebih jauh masuk membahas permasalahan yang ada, alangkah baiknya menilik kepada pokok pikiran, uraian singkat yang menjadi latar belakang dan alasan lahirnya UUAP sebagaimana yang tertuang didalam konsiderans sebagai berikut:

“Menimbang: a. bahwa dalam rangka meningkatkan kualitas penyelenggaraan pemerintahan, badan dan/atau pejabat pemerintahan dalam menggunakan wewenang harus mengacu pada asas-asas umum pemerintahan yang baik dan berdasarkan ketentuan peraturan perundangundangan; b. bahwa untuk menyelesaikan permasalahan dalam penyelenggaraan pemerintahan, pengaturan mengenai administrasi pemerintahan diharapkan dapat menjadi solusi dalam memberikan pelindungan hukum, baik bagi warga masyarakat maupun pejabat 
pemerintahan; c. bahwa untuk mewujudkan pemerintahan yang baik, khususnya bagi pejabat pemerintahan, undang-undang tentang administrasi pemerintahan menjadi landasan hukum yang dibutuhkan guna mendasari keputusan dan/atau tindakan pejabat pemerintahan untuk memenuhi kebutuhan hukum masyarakat dalam penyelenggaraan pemerintahan; $d$. bahwa berdasarkan pertimbangan sebagaimana dimaksud dalam huruf a, huruf $b$, dan huruf $c$ perlu membentuk Undang-Undang tentang Administrasi Pemerintahan."

Penulis berpendapat UUAP bertujuan untuk memberikan jaminan dan kepastian hukum dalam penyelenggaraan pemerintahan di Indonesia, UUAP memberikan ruang kepada Badan dan/atau Pejabat Pemerintahan atau penyelenggara negara lainnya untuk memberikan pelayanan yang berkualitas kepada masyarakat dalam penyelenggaraan pemerintahan, selain itu juga UUAP memberikan perlindungan hukum terhadap Badan dan/atau Pejabat Pemerintahan atau penyelenggara negara lainnya dalam melaksanakan fungsi pemerintahan dalam hal ini penggunaan wewenang, diharapkan dengan lahirnya UUAP, Badan dan/atau Pejabat Pemerintahan atau penyelenggara negara lainnya merasa terlindungi dari kriminalisasiterkait dengan penyalahgunaan kewenangan, karena selama ini yang terjadi apabila sedikit saja kesalahan administrasi dalam penyelenggaraan pemerintahan padahal didalam pelaksanannya tidak ada sedikitpun niat jahat untuk melakukan penyalahgunaan kewenangan sudah langsung dijerat dengan Pasal 3 UU No 20 Tahun 2001 tentang Perubahan atas UU No 31 Tahun 1999 tentang Pemberantasan Tindak Pidana Korupsi (UUPTPK). Perlindungan hukum didalam UUAP terhadap Badan dan/atau Pejabat Pemerintahan atau penyelenggara negara lainnya terkait penyalahgunaan wewenang sangat penting guna lancarnya pemerintahan yang bertujuan untuk pembangunan, sebagaimana diketahui pejabat atau pemegang kewenangan selama ini tidak leluasa menggunakan kewenangannya dikarenakan selalu dihantui dengan perasaan takut terjerat 
tindak pidana korupsi sehingga serapan anggaran pemerintahan menjadi rendah dan pembangunan menjadi terhambat.

Merujuk kepada pengujian terhadap penyalahgunaan wewenang di PTUN (Pasal 21), pejabat atau pemegang kewenangan dapat menguji wewenang yang dilakukannya apakah perbuatan tersebut termasuk penyalahgunaan wewenang atau tidak, apabila memang terjadi penyalahgunaan wewenang maka hal tersebut dapat dijadikan dasar oleh aparat penegak hukum untuk melakukan penyelidikan ataupun penyidikan dugaan tindak pidana korupsi terhadap pelaku penyalahgunaan wewenang, sedangkan apabila didalam pengujian terhadap penyalahgunaan wewenang oleh PTUN tidak terbukti maka barang tentu perbuatan tersebut tidak dapat dijadikan dasar untuk melakukan penyelidikan ataupun penyidikan terhadap pelaku penyalahgunaan kewenangan dalam tindak pidana korupsi berdasarkan UU No 20 Tahun 2001 tentang Perubahan atas UU No 31 Tahun 1999 tentang Pemberantasan Tindak Pidana Korupsi, hal ini merujuk kepada tujuan dibentuknya UUAP.Sehingga dengan adanya ketentuan penyalahgunaan wewenang dalam UUAP memiliki dampak positif terhadap pemberantasan tindak pidana korupsi, selain dari UUAP dijadikan sebagai upaya pencegahan tindak pidana korupsi, UUAP juga dapat mempermudah aparat penegak hukum mengetahui adanya penyalahgunaan kewenangan, karena UUAP membuka peluang untuk melakukan pengujian terhadap tindakan penyalahgunaan oleh pejabat atau pemegang kewenangan. Sebaliknya UUAP menjamin dan melindungi pejabat atau pemegang kewenangan dalam menjalankan pemerintahan.

Pendapat para ahli terkait dengan penyalahgunaan wewenang dalam UU No 30 Tahun 2014 tentang Administrasi Pemerintahan (UUAP) dalam hubungan pemberantasan tindak pidana korupsi sebagai berikut:

- Ketua Mahkamah Agung Republik Indonesia dalam sambutannyapada Seminar Nasional IKAHI dalam Rangka Hut IKAHI ke 62 dijakarta 26 Maret 2015: ( Pimpinan Pusat Ikatan Hakim Indonesia, 2015. 11-13) Seminar ini mengupas tuntas tentang unsur Penyalahgunaan Wewenang 
yang dilakukan oleh pejabat pemerintahan yang melakukan penyalahgunaan wewenang. UU No 30 Tahun 2014 tentang Administrasi Pemerintahan mengatur wewenang pemerintahan dan sekaligus instrument pengontrol hukum dalam penegakan hukum administrasi (Pemerintahan) yang dilakukan oleh pejabat pemerintahan.Penegakan hukumnya melalui pengadilan akan dilakukan oleh Pengadilan TUN. Sementara itu telah ada mekanisme penegakan hukum terhadap penyelengggara Negara yang melakukan tindak pidana korupsi yang didalamnya terdapat unsur "Penyalahgunaan Kewenangan" melalui pengadilan tindak pidana korupsi (Tipikor), sehingga terdapat dua titik singgung kewenangan mengadili antara kedua badan peradilan terhadap pejabat pemerintahan selaku penyelenggara Negara yang melaksanakan fungsi pemerintahan.Dengan demikian terdapat 2 (dua) persfektif penegakan hukum karena dalam UU No 20 Tahun 2001 tentang Pemberantasan Tindak Pidana Korupsi, memaknai salah satu bentuk tindak pidana korupsi adalah Penyalahgunaan Wewenang, sementara dari Persfektif UU No 30 Tahun 2014 tentang Administrasi Pemerintahan, pejabat yang menyalahgunakan wewenang harus dipertanggungjawabkan secara hukum menurut prosedur penyelesaian diranah hukum administrasi.Sebagai pengaruh adanya dua dikotomi ranah hukum, yaitu hukum administrasi dan hukum pidana korupsi dalam praktek penyelesaian perkara penyalahgunaan wewenang secara keilmuan hukum dapat menimbulkan dua akibat: Pertama, terhadap perkara yang sama, dalam hal ini penyalahgunaan wewenang, tetapi penyelesaian dilakukan oleh dua ranah hukum publik yang berbeda cabang keilmuannya, konsekuensinya, tentu dapat mengahasilkan putusan yang berbeda. Kedua, adanya dikotomi tersebut menimbulkan kesulitan dalam mencapai suatu kebenaran (The Objectivity) yang komprehensif. Meskipun dalam penanganan tindak pidana korupsi, khususnya yang berkenaan dengan penyalahgunaan wewenang ikut menyertakan ranah hukum administrasi, hal ini tidak dipandang sebagai 
upaya menghambat pemberantasan korupsi, dikarenakan, penyelesaian masalah korupsi termasuk yang diprioritaskan dalam penegakan hukum dan merupakan agenda utama dalam reformasi brirokrasi. Oleh karenanyaa perlu ada kajian secara mendalam tentang pemahaman "Penyalahgunaan wewenang" disebabkan Hakim Pengadilan TUN diberi kewenangan dalam penegakan hukum materil pada pejabat pemerintahan sebagaimana diatur dalam Undang-Undang Administrasi Pemerintahan (UUAP), sedangkan Hakim Pengadilan Tipikor diberi kewenangan dalam penegakan hukum materil pemberantasan tindak pidana korupsi menurut ketentuan Undang-Undang Tipikor. Dengan merujuk pada Pasal 21 UUAP dan Ketentuan Pasal 3 UU Tipikor tersebut, jika pengujian penyalahgunaan wewenang dilakukan oleh PTUN apakah hal tersebut justru akan menguatkan ataukah sebaliknya, melemahkan upaya pemberantasan korupsi, karena ada kekhawatiran public, kalau lahirnya ketentuan tersebut PTUN akan menjadi tempat untuk bersembunyi para koruptor. Akan tetapi disisi lain, bagi pejabat publik yang taat hukum dan beritikad baik apakah tidak pantas untuk mendapatkan perlindungan hukum atas tindakan yang telah dilakukannya dalam penyelenggaraan pemerintahan.Terhadap issue dan permasalahan tersebut diatas, kita percaya pembuat undang-undang telah melakukan upaya harmonisasi atas eksistensi dari ketentuan dua pasal tersebut diatas, namun sangat dimungkinkan akan adanya potensi antinomy nermen dalam tataran implementasinya. Keadaan tersebut akan menyebabkan adanya kontra produktif dalam penegakan hukum pemberantasan tindak pidana korupsi.

- Prof. Dr. Guntur Hamzah, (Pimpinan Pusat Ikatan Hakim Indonesia, 2015. 92-100) Latar belakang dibentuknya UUAP, diantaranya adalah untuk mengatasi problem kriminalisasi kebijakan, karena adakalanya dalam praktek kesalahan pejabat pemerintahan hanya melakukan kesalahan yang sifatnya administrasi (tidak melakukan korupsi serupiah pun), akan tetapi dianggap melakukan tindakan pidana.Dasar Pemikiran 
utama UUAP:Kebutuhan untuk menjamin standar proses pengambilan keputusan;Membangun system komunikasi timbal balik antara warga Negara dengan pejabat pemerintahan dalam reformasi birokrasi.RezimUUAP, sudah memasuki rezim atau generasi dimana hubungan komunikasi timbal balik warga Negara dengan badan dan/atau pejabat pemerintahan, terutama dalam melakukan pelayanan publik.Dalam pemberantasan korupsi dapat ditinjau dari dua rezim hukum, yaitu rezim Hukum Administrasi Negara lebih mengutamakan preventif, sedangkan rezim hukum pidana merupakan upaya tindakan represif.Penyelesaian Hukum Administrasi Negara bersifat reparatoir, artinya ketika ada persoalan harus dapat diselesaikan secara langsung pada saat itu juga. Seperti hasil pemeriksaan APIP (Aparat Pengawasan Intern Pemerintah), apabila ada pelanggaran administrasi, maka diselesaikan dengan segera melalui Hukum Administrasi Negara sehingga segera diperbaiki kesalahan administrasi itu. Apabila ada kaitannya dengan kerugian Negara, maka kalau dalam rangka menjalankan jabatannya dan terbukti tidak melakukan penyalahgunaan wewenang maka kerugian itu merupakan tanggungjawab negara, akan tetapi kalau ada kelalaian sehingga terbukti melakukan penyalahgunaan wewenang maka itu menjadi tanggungjawab pribadi si pejabat tersebut.Apabila ada permasalahan hasil temuan antara APIP dan BPK, maka perlu ada komunikasi diantara kedua lembaga ini. Untuk memastikan apakah ada kesalahan administrasi atau kerugian Negara atau tidak, akan tetapi lebih diutamakan lebih dahulu diselesaikan melalui ranah Hukum Administrasi Negara.Pada saat UUAP didesain tidak ada perbedaan prinsipil atau subtantif antara wewenang dan kewenangan, yang ada hanya perbedaan gradual. Perbedaan gradual, bahwa ketika yang melakukan kewenangan maka addessat-nya adalah lembaga, dan apabila yang menjalankan itu pejabat pemerintahan maka itu merupakan wewenang. Jadi, kalau ada perbedaan atau dipisahkan antara wewenang dan kewenangan akan menimbulkan kontradiksi. 
- Prof. Dr. Zudan Arif Fakrulloh, S.H., M.H., dalam persfektif pembentukannya, UU No 30 Tahun 2014 tentang Administrasi Pemerintahan, berada diujung hilir, yang hulunya ada di UU Aparatur Sipil Negara (UU No5 Tahun 2014), dan tujuannya adalah mewujudkan good governance. Berawal dari UU ASN, kemudian mengalir profesi ASN dibawa ke UU Pemerintahan Daerah (UU No. 23 Tahun 2014), disinilah mulai mengadopsi paradigma restorative justice. Mulai mengedepankan unsur pencegahan dan penindakan dilakukan secara bersamaan, UU Pemda secara eksplisit menyatakan bahwa masyarakat yang keberatan dapat mengadukan kepada Aparat penegak hukum, setelah ada pengaduan aparat penegak hukum berkoordinasi dengan aparat pengawas internal pemerintahan (APIP) seperti: BPKP, Inspektorat Jenderal, atau Inspektorat Provinsi/Kabupaten/Kota. Bila tindakan kesalahan bersifat administrative diselesaikan secara internal, sedangkan bila ada indikasi tindak pidana maka diselesaikan melalui aparat penegak hukum. UU Pemda ini belum menyelesaikan permasalahan apa tolak ukur kesalahan itu merupakan bersifat administrative atau pidana, kemudian dibuatlah hukum materilnya melalui UUAP.Ada 4 (empat) konsep penting dalam UUAP, yaitu:Tindakan, Keputusan, Wewenang;Kewenangan.Apabila dicermati mengenai konsep tindakan dan/atau keputusan pejabat pemerintahan baik dalam UUAP, UU ASN, dan UU Pemda, sebetulnya sedang dibangun paradigma baru dalam berhukum antara pendekatan pencegahan, penindakan, dan restorative justice dilakukan secara bersamaan.Ketiga undang-undang ini filosofisnya untuk mewujudkan good governance. Artinya ditujukan kepada aparatur pemerintahan yang beritikad baik dan jujur. Jadi, ketiga undang-undang ini tidak untuk melindungi aparatur pemerintahan yang beritikad buruk dan tidak jujur.Maksud dalam UUAP yang dimaksud tindakan pemerintahan bukan hanya yang bersikap aktif, akan tetapi juga yang bersikap diam (pasif) juga, dan dapat dilakukan oleh siapa saja berdasarkan pelimpahan 
wewenang (atribusi, delegasi, atau mandat) yang ada. Adapun, keputusan hanya dapat dilakukan oleh badan dan/atau pejabat pemerintahan.Permohonan yang diajukan ke PTUN adalah oleh pejabat atau badan, dapat pejabat tinggi atau pejabat aparatur penyelenggaraan pemerintahan yang berkepentingan terhadap adanya LHP, dan yang dinilai oleh Hakim TUN adalah tindakan dari badan atau pejabat yang bersangkutan apakah ada unsur penyalahgunaan wewenang atau tidak.

- Prof. Dr. Romli Atmasasmita, S.H., L.LM, Ada perubahan politik hukum (yang merupakan kemauan pemerintahan dan DPR) dalam pembentukan peraturan perundang-undangan terkait tindak pidana korupsi, termasuk UUAP. Kelemahan dari UU Tipikor, khususnya Pasal 3, sebelumnya tidak ada batasan jumlah kerugian Negara yang dianggap sebagai tindakan korupsi kalau dua unsur sudah terpenuhi, dan tidak ada pengertian penyalahgunaan kewenangan. UUAP ini sudah memberikan pengertian penyalahgunaan wewenang yaitu melampaui batas kewenangan, mencampuradukan kewenangan, dan sewenang-wenang, sehingga dalam implementasinya para penyidik dan penuntut perlu memahami UUAP ini.Perlu adanya keselarasan dalam penegakan hukum penyalahgunaan wewenang, antara penegakan hukum pidana di pengadilan tipikor dan penegakan hukum administrasi di PTUN, agar tidak adanya tumpang tindih atau menghasilkan putusan yang saling bertentangan. Mahkamah Agung perlu menyikapi hal ini.Dengan adanya UUAP ini, maka kedepan UU Tipikor dan UU KPK perlu direvisi yang mengarah pada pencegahan korupsi.Arahnya penegakan hukum pada dasarnya adalah: pencegahan, penindakan dan restiratif (pemulihan).

- Prof. Dr. Indriyanto Seno Adji, S.H., M.H., pada prakteknya, pencegahan korupsi hasilnya lebih baik dari pada penindakan korupsi. Dalam penindakan korupsi jangan sampai melanggar hak-hak tersangka.Penindakan dalam arti Law Enforcement pada saat sekarang ini yang diutamakan adalah dengan cara-cara yang beretika. 
- Prof. Dr. Solly Lubis, S.H., UUAP merupakan hukum materil HAN, sedangkan PTUN banyak mengatur hukum formil HAN. Perlu adanya harmonisasi antara ketentuan yang mengatur unsur penyalahgunaan wewenang/kewenangan dalam UU AP (hukum materil HAN) dan UU Tipikor (hukum materil hukum pidana korupsi). UUAP merupakan Lex Generalis pada dasarnya sebagai upaya dalam rangka untuk meningkatkan pemerintahan yang lebih baik (good governance) yaitu dalam rangka preventif, sedang UU Tipikor merupakan Lex Spesialis dititikberatkan pada tindakan represif.

- H. Arsyad Sanusi, S.H., M.H, Norma penyalahgunaan wewenang/kewenangan ada konflik rule antara kedua undang-undang tersebut. UUAP dalam hal penyalahgunaan wewenang menganut delik materil, sedang UU tipikor menganut delik formil. Jadi perlu ada harmonisasi dalam perubahan undang-undang nantinya.Pemberantasan Korupsi selama ini belum menganut crime control, artinya: legal culture yang cocok untuk bangsa Indonesia berupa due process modern yang lebih hati-hati dalam penindakan terhadap kasus korupsi, bukan tangkap dulu pelaku baru pembuktiannya belakangan, tetapi harus ada pembuktian dulu baru dilakukan penangkapan.

Bahwa merujuk pendapat para ahli diatas, telah diketahui tujuan dari pada UUAP mengatur ketentuan pengujian penyalahgunaan wewenang adalah untuk menjamin kepastian hukum kepada pejabat pemegang wewenang dalam menjalankan pemerintahan, karena melalui pengujian tindakan penyalahgunaan wewenang dalam ranah administratif dapat diketahui apakah wewenang tersebut telah dijalankan sesuai dengan aturan hukum dan itikad baik ataukah dengan niat jahat. UUAP juga melindungi bagi para pejabat yang menjalankan wewenang sesuai prosedur hukum dan itikad baik, sehingga tidak serta merta tindakan penyalahgunaan wewenang yang dilakukan dapat dikualifikasi sebagai tindak pidana korupsi dalam ranah hukum pidana. Lahirnya UUAP membantu aparat penegak hukum untuk mengurangi tingkat korupsi yang terjadi di Indonesia, karena melalui 
ranah administrasi menggunakan UUAP dapat mewujudkan restoratif justice, sehingga tidak semua penyalahgunaan wewenang berakhir dengan pidana.

II. Apa konsekuensi hukum dari perbedaan hasil penegakan hukum terkait pengujian penyalahgunaan wewenang menurut hukum administrasi dengan penegakan hukum dalam tindak pidana korupsi ?

Penulis berpendapat tidak ada konsekuensi hukum terhadap perbedaan hasil penegakan hukum terkait penyalahgunaan kewenangan menurut hukum administrasi dan penegakan hukum terhadap menyalahgunakan kewenangan dalam tindak pidana korupsi karena antara ranah administrasi dan pidana jelas berbeda, walaupun pada ranah hukum administrasi menyatakan bahwa tidak ada penyalahgunaan kewenangan akan tetapi dalam ranah pidana ditemukan niat jahat dari pada perbuatan menyalahgunakan kewenangan tersebut oleh pejabat yang berwenang maka proses pidananya tetap berjalan sehingga proses penegakan hukum administrasi tidak menghalangi proses penegakan hukum pidana. Begitu juga sebaliknya proses penegakan hukum pidana tidak melarang dan membatasi adanya penegakan hukum administrasi baik dalam hal pengujian perbuatan penyalahgunaan kewenangan dikarenakan hukum pidana merupakan Ultimum Remedium.

Pada unsur Menyalahgunakan Kewenangan menurut hukum pidana terkandung makna kesengajaan, kelalaian, melawan hukum, kesalahan dan pertanggungjawaban pidana. Dari makna yang terkandung didalam menyalahgunakan kewenangan dapat dijadikan tolak ukur untuk menyatakan seseorang telah menyalahgunakan kewenangan berdasarkan hukum pidana. Kesengajaan, kelalaian, melawan hukum, kesalahan dan pertanggungjawaban pidana, sebagai pembeda antara unsur menyalahgunakan kewenangan menurut hukum pidana dan penyalahgunaan wewenang menurut hukum administrasi.Walaupun kesengajaan, kelalaian, melawan hukum, kesalahan dan pertanggungjawaban pidana yang merupakan pembeda unsur Menyalahgunakan Kewenangan dalam hukum pidana dan Penyalahgunaan 
wewenang dalam hukum administrasi tidak tertulis secara nyata pada rumusan delik akan tetapi unsur ini tidak dapat dipisahkan dari hukum pidana. Hukum pidana memiliki kaitan erat dengan kesengajaan melakukan suatu perbuatan melawan hukum (perbuatan yang dilarang oleh undangundang), dan perbuatan tersebut dapat dipertanggungjawabkan kepada si pelaku, sehingga si pelaku dapat dikatakan sebagai orang yang telah melakukan tindak pidana.

Kesengajaan(opzet) menurut meomorie van toelichting berarti de bewuste richting van den wil op een bepaald misdriff (kehendak yang disadari yang ditujukan untuk melakukan kejahatan tertentu) yang merupakan willens en wetens (dikehendaki dan diketahui). (Andi Hamzah. 2015, 146)Kesengajaan menggunakan kewenangan, dalam hal ini menghendaki menggunakan kewenangan tersebut menyimpang dari tujuan diberikannya wewenang yang berdasarkan peraturan perundang-undangan dan mengetahui akibat dari pada penyimpangan wewenang yang diberikan oleh peraturan perundang-undangan tersebut, atau dengan kata lain dengan secara sadar menyalahgunakan kewenangan serta menginsafi akibat yang timbul dari perbuatan menyalahgunakan kewenangan tersebut. Peraturan perundangundangan yang dimaksud disini adalah ketentuan hukum pidana yang mengatur secara khusus tentang larangan menyalahgunakan kewenangan. Kesengajaan disini bisa juga diartikan sebagai niat jahat didalam melakukan suatu perbuatan. Berdasarkan pengertian niat diatas telah jelas bahwa niat sama artinya dengan kesengajaan, sehingga didalam menyalahgunakan kewenangan berdasarkan hukum pidana haruslah ada niat jahat atau kesengajaan untuk berbuat kejahatan.Tindak pidana menyalahgunakan kewenangan dalam hukum pidana haruslah ada Niat jahat yang berada dalam diri si pelaku dan dituangkan atau diwujudkan dalam permulaan pelaksanaan perbuatan jahat atau perbuatan melawan hukum, serta perbuatan tersebut selesai (berbeda dengan percobaan melakukan tindak pidana yang mana perbuatannya tidak selesai). Niat jahat menggunakan kewenangan yang tidak sesuai atau menyimpang dari tujuan diberikannya 
wewenang tersebut, kemudian dilanjutkan dengan perbuatan permulaan pelaksanaan yakni bisa berupa tidak melaksanakan kewajiban yang harus dilakukan dalam kewenangan itu atau melakukan larangan dan melakukan perbuatan minyimpang dari tujuan diberikannya kewenangan itu berdasarkan peraturan perundang-undangan, dan mengetahui terlebih dahulu akibat yang ditimbulkan apabila larangan dan kewajiban yang ada dalam kewenangan tersebut tidak dilaksanakan sebagimana tujuannya.

Kelalaian(culpa) menurut meomorie van toelichting terletak antara sengaja dan kebetulan, culpa lebih ringan dari kesengajaan. Hazewinkel Suringa menyatakan delik culpa merupakan delik semu (quasidelict), sehingga dilakukan pengurangan pidana terhadap pelaku culpa.(Andi Hamzah. 2015, 167-168)Kelalaian melaksanakan kewenangan yakni tidak hati-hati melaksanakan kewenangan sebagaimana kewenangan yang telah diberikan, sehingga mengakibatkan wewenang yang diberikan tidak berjalan sebagaimana mestinya wewenang itu dijalankan. Ketidakhati-hatian melaksanakan kewenangan berdasarkan ketentuan hukum pidana yang mengatur secara khusus tentang larangan menyalahgunakan kewenangan.

Melawan hukum meliputi sifat melawan hukum formil, Perbuatan melawan hukum formil (formeel wederrechtelijkheid) adalah perbuatan yang bertentangan dengan aturan hukum tertulis yakni peraturan perundangundangan pidana yang berlaku. Sifat melawan hukum materil, Perbuatan melawan hukum materil (materieel wederrechtelijkheid) adalah perbuatan yang bertentangan dengan aturan hukum tidak tertulis yakni hukum kebiasaan dan rasa keadilan dalam masyarakat serta nilai kepatutan didalam masyarakat.(Eddy O.S. Hiariej. 2016, 237-242)

Melawan hukum menggunakan kewenangan meliputi menggunakan kewenangannya bertentangan dengan hukum tertulis (peraturan perundang-undangan) ataupun hukum tidak tertulis (apabila didalam hukum administrasi hukum tidak tertulis merupakan asas umum pemerintahan yang baik), akan tetapi melawan hukum disini tetap berpedoman pada asas legalitas sebagai dasar hukum pidana.Melawan 
hukum menggunakan kewenangan bisa dikarenakan melanggar dari tujuan kewenangan itu diberikan oleh undang-undang, atau melawan hukum melaksanakan kewenangan dikarenakan dalam menjalankan kewenangan yang diberikan bertentangan dengan ketentuan hukum pidana yang secara khusus mengatur tentang larangan menyalahgunakan kewenangan seperti halnya Pasal 3 UU No 31 Tahun 1999 Jo UU No 20 Tahun 2001 Tentang Pemberantasan Tindak Pidana Korupsi.Melawan hukum menggunakan kewenangan / menyalahgunakan kewenangan dengan cara melawan hukum disini diartikan tersirat didalam unsur Pasal 3 UUPTPK yang merupakan aturan hukum pidana, yang artinya untuk menilai seseorang yang memiliki kewenangan telah melawan hukum adalah dengan cara menggunakan kewenangannya bertentangan dengan ketentuan hukum pidana yang secara khusus melarang melakukan perbuatan menyalahgunakan kewenangan, dalam hal ini UUPTPK.

Kesalahanmenurut Simons "seseorang yang menurut undang-undang dianggap bahwa ia berbuat salah, jika dia dapat menyadari perbuatannya melawan hukum dan sesuai dengan itu dia dapat menentukan kehendak perbuatan tersebut".(Eddy O.S. Hiariej. 2016, 157-163)

Kesalahan dalam melaksanakan kewenangan meliputi adanya perbuatan yang dapat dicela dari kewenangan yang dijalankan oleh pelaksana kewenangan, dalam hal ini kewenangan yang melawan hukum (melanggar hukum tertulis / peraturan perundang-undangan dan hukum tidak tertulis) serta dapat dipertanggungjawabkan menurut hukum pidana atas kesalahan dari pelaksanaan kewenangan tersebut. Bahwa kesalahan dalam hal ini adalah kesalahan menurut hukum pidana meliputi pelaksanaan kewenangan tersebut melanggar ketentuan hukum pidana yang mengatur secara khusus tentang larangan menyalahgunakan kewenangan.

Pertanggungjawaban pidana menurut Vos mendefinisikan pertanggungjawaban pidana merupakan kelakuan yang dapat dicela kepadanya, bukan celaan etis tapi celaan secara hukum. (Eddy O.S. Hiariej. 2016, 155-157) Pertanggungjawaban kewenangan menurut hukum pidana 
merupakan pertanggungjawaban secara pribadi, apabila kewenangan yang diberikan berdasarkan peraturan perundang-undangan tersebut disalahgunakan. Berbeda dengan pertanggungjawaban wewenang menurut hukum administrasi menitikberatkan kepada pertanggungjawaban jabatan dari si pemangku wewenang, sehingga tidak dapat dibebankan kepada pribadi sebagaimana hukum pidana. Menurut hukum pidana sesuai dengan pengertian pertanggungjawaban pidana diatas maka adanya hubungan psikis si pelaksana kewenangan yang mengakibatkan kewenangan yang ada padanya melahirkan perbuatan pidana dan dapat dicela berdasarkan hukum pidana sehingga kewenangan tersebut bertentangan dengan ketentuan hukum pidana yang mengatur secara khusus tentang larangan menyalahgunakan kewenangan.

\section{KESIMPULAN}

Berdasarkan hal tersebut diatas dapat diambil kesimpulan terkait penyalahgunaan wewenang menurut hukum administrasi dalam hal ini UUAP merupakan upaya hukum preventif terhadap terjadinya tindak pidana korupsi sedangkan penyalahgunaan kewenangan menurut hukum pidana (UUPTPK) merupakan upaya hukum represif terhadap tindakan penyalahgunaan kewenangan yang dilakukan pejabat negara. Penyalahgunaan wewenang baik menurut hukum administrasi ataupun hukum pidana memiliki ranah hukum masing-masing, walaupun demikian keduanya saling memiliki hubungan yang erat, disatu sisi UUAP menjamin kepastian hukum terhadap tindakan pejabat negara didalam menjalankan pemerintahan, sebaliknya UUPTPK melindungi kepentingan negara terhadap tindakan pejabat negara yang korup atau melanggar ketentuan peraturan perundang-undangan yang pastinya merugikan keuangan negara dan menghambat jalannya pemerintahan serta pembangunan. Konsekuensi hukum diterapkannya pengujian penyalahgunaan kewenangan berdasarkan UUAP adalah tindakan pejabat negara yang diputus berdasarkan pengujian bukan merupakan tindakan penyalahgunaan kewenangan maka tindakan 
tersebut tidak dapat dijadikan dasar untuk Aparat Penegak hukum masuk untuk melakukan penyelidikan ataupun penyidikan tindak pidana korupsi penyalahgunaan kewenangan, sedangkan apabila menurut pengujian di PTUN terdapat unsur penyalahgunaan kewenangan (dengan adanya niat jahat dalam hukum pidana), maka terhadap tindakan pejabat negara tersebut dapat dilakukan penyelidikan ataupun penyidikan tindak pidana korupsi. Pengujian penyalahgunaan kewenangan ini dimaksudkan untuk melindungi tindakan pejabat negara yang memiliki itikad baik dalam menjalankan kewenangannya.

\section{DAFTAR PUSTAKA}

Hamzah Andi, 2015. Hukum Pidana. PT Sofmedia. Jakarta

Hiariej.Eddy O.S,2016. Prinsip-Prinsip Hukum Pidana. Cahaya Atma Pustaka. Yogyakarta

Latief Abdul, 2010. Hukum Administrasi Dalam Praktik Tindak Pidana Korupsi, Prenada Media Group. Jakarta

M. Hadjon Philipus, Djatmiati Tatiek Sri, Addhink G. H., ten Berge J.B.J.M.,2011. Hukum Administrasi dan Tindak Pidana Korupsi. Gadjah Mada University Press. Yogyakarta

Marzuki Peter Mahmud, 2005. Penelitian Hukum. Kencana Prenada Media Group. Surabaya

Pimpinan Pusat Ikatan Hakim Indonesia (PP IKAHI), 2015. Undang-Undang Administrasi Pemerintahan Dalam Upaya Pemberantasan Korupsi, Hasil Seminar Nasional Dalam Rangka Hari Ulang Tahun IKAHI Ke - 62 "Peradilan Tindak Pidana Korupsi Ke Depan, 26 Maret 2015" Sinar Grafika. Jakarta

Undang-Undang Republik Indonesia Nomor 20 Tahun 2001 tentang Perubahan atas Undang-Undang Republik Indonesia Nomor 31 Tahun 1999 tentang Pemberantasan Tindak Pidana Korupsi.

Undang-Undang Republik Indonesia Nomor 30 Tahun 2014 tentang Administrasi Pemerintahan. 